\title{
The biological standard of living in early South Korea: Physical well-being based on body mass indices, 1940s to 1950s
}

\author{
Daniel Schwekendiek · Heejin Park
}

\begin{abstract}
This study fills a gap in the literature on the physical well-being of humans by employing BMI measurements of 89 Koreans measured from the early 1940s to mid-1950s. This period is of special historical concern since it coincides with the end of World War II, during which Japan utilized the Korean peninsula as a supply base for its war efforts, the disruptive American occupation period of Korea (1945-1948), the destructive Korean War (1950-1953), and the chaotic early years after the war. This study draws on records of employees from a large Korean bank. BMI values were lower in the latter period, indicating that living standards must have declined after the Korean War. While the war destroyed Korea's economy, relief aid prevented a total collapse during war times. However, international massive grain programs such as PL 480 had not yet been implemented in the mid-1950s, leaving people vulnerable directly after the war. Anthropometric comparisons with historical populations in the United States as well as with pre-modern to contemporary Koreans are made in a latter section of this paper.
\end{abstract}

Keywords: Korea, Asia, human wellbeing, standard of living, economic history, anthropometry

\section{Introduction}

Over the last few decades, the concept of "biological standard of living" has been established in the literature on human well-being (Komlos and Baten 1998; Komlos and Kriwy 2003; Koepke and Baten 2005; Baten and Blum 2012). In addition to income, the biological standard of living focuses on health and nutritional improvements in populations, thereby encompassing biological components of human welfare and economic development. The biological standard of living is typically proxied by demographic and anthropometric indicators such as morbidity, life expectancy, and frequently height (Steckel 1995; Steckel 2009).

Previous research on the biological standard of living in Korea has focused on height trends of the pre-modern Joseon Dynasty (Pak 2011; Shin, Oh et al. 2012; Lewis, Jun et al. 2013), Colonial Korea (Kimura 1993; Choi and Schwekendiek 2009; Kim and Park 2011), as well as South Korea (Schwekendiek and Jun 2010), and North Korea (Pak 2004; Schwekendiek 2008a; Schwekendiek 2008b). 
Findings related to the height of Korean men can be summarized as follows. While the mean height of people in underdeveloped North Korea stagnated during the second half of the twentieth century (Pak, 2004; Pak et al., 2011), their counterparts living in developed South Korea experienced a secular trend in height during the same period (Schwekendiek and Jun, 2010). South Koreans were even found to be the tallest among East Asians as a result of healthy and wealthy living conditions in combination with animal protein programs initiated by the government (Schwekendiek and Jun, 2010). Heights of the lowest class (Kim and Park, 2011) as well as the lower to middle class in early Colonial Korea (Choi and Schwekendiek, 2009) slightly improved by $2 \mathrm{~cm}$, which might be attributed to Japanese agricultural, health, and sanitation reforms. The height of Korean men born in the Joseon Dynasty was estimated at $161 \mathrm{~cm}$ based on osteometric reconstructions using modern Japanese skeleton references (Shin et al., 2012). However, the mean height of men was estimated at $164 \mathrm{~cm}$ based on 'broad' Mongoloid skeleton references (Pak, 2011). Based on data measured from living males, the height of Joseon Dynasty Korean men born from the mid-sixteenth to early eighteenth centuries was estimated at $166 \mathrm{~cm}$ (Lewis et al., 2013), indicating that East Asians enjoyed similar biological living standards as Frenchmen at that time.

While biological living standards in contemporary and pre-modern Korea have been well studied, there has been no report on the critical interwar period in Korea, which lasted from World War II (1939-1945) to the Korean War (1950-1953). This interwar period is of special historical concern since it coincides with the end of World War II, during which Japan utilized the Korean peninsula as a supply base for its war efforts, the disruptive American occupation period of Korea (1945-1948), the destructive Korean War (1950-1953), and the chaotic early years after the war.

The purpose of this paper is to shed light on the biological standard of living in interwar Korea (and the immediate years before and thereafter), as this was a very critical period characterized by crises, wars, macroeconomic shock, corruption and, in short, chaos. Previous studies focused on Koreans born in the early colonial period of the 1910s to 1920s (Choi and Schwekendiek, 2009; Kim and Park, 2011), whereas studies on contemporary South Koreans focused on those born as early as the mid-1950s (Schwekendiek and Jun, 2010). Therefore, this paper fills a gap in the literature while offering a unique opportunity to study living standards under extreme conditions.

Indeed, after Japan raided Pearl Harbor in 1941, living conditions noticeably deteriorated in Colonial Korea as the Japanese fully mobilized for war against the United States. Mineral, agricultural, and other vital resources were increasingly removed by the Japanese, putting Koreans under more pressure to survive. A Korean experiencing colonization (Kang 2001:16) remembers Japanese strict rule as follows:

Grass and tree bark, and this is literally what we lived on ... We also picked up acorns from the mountain in the autumn and ate them during the winter. These we had to soak for many days to get rid of the acrid smell and the caustic chemicals. Yes, we really did live like that. Of all the households in the village ... only about five or six were still eating grains of any kinds. 
Since the Japanese held all key positions in Colonial Korea and also refrained from training Korean engineers and technicians, Koreans were not able to repair and operate cars and machines on their own, which hampered agricultural and industrial production.

After Japan lost the war, the Allies placed Korea under a temporary Northern and Southern trusteeship (1945-1948). While the Soviet Union installed a Korean puppet regime in the North, Southern Korea was ruled by an American military government. The provisional division of the Korean peninsula into two halves posed large challenges for policy planners in both occupied zones. While the industrial North was cut-off from food production, the agricultural South was cut-off from stable energy supplies as well as fertilizers produced in the North, thereby hampering food production in the South. Interestingly, the two Germanys, which were also divided around that time through the outbreak of the Cold War, faced a similar structural problem after division (Giersch, Paqué et al. 1992; Steiner 2010).

To make things worse, after Japanese colonization, millions of Koreans returned from Japan, Manchuria (now China), and Sakhalin Island (now Russia) or fled from the Communist North to the South, all of which dramatically increased food demand in Korea and aggravated the situation. As noted by a foreign observer at that time (Nahm 1993:227):

[The] situation is getting worse. There is rampant inflation. Consumer goods and coal are virtually nonexistent. Food distribution is inequitable ... Transportation equipment is breaking down. Unemployment is rising to dangerous proportions ... Hunger is rapidly spreading and will presently result in starvation in many areas by mid summer.

In light of Soviet-American antagonism after World War II, separate elections were held in both occupied Korean zones, which in turn led to formal establishment of the Republic of Korea (widely known as South Korea) and the Democratic People's Republic of Korea (widely known as North Korea) in 1948.

In 1950, the Cold War escalated into an armed war when North Korea invaded South Korea in order to take control of the entire peninsula. Only the U.S.-led UN intervention prevented defeat of the South but not without extremely devastating effects. In fact, the death toll among the civilian population exceeded that of the Vietnam War (Cumings, 2010). The United States, having complete air dominance, dropped more bombs on Korea than on Japan during World War II in order to minimize American casualties, which resulted in major costs to the Korean civilian population and local infrastructure. An American soldier fighting in Korea (Eargle 1952: 28) wrote in his diary the following:

Close to fifty-five tons of explosive were used during strike and pilots described one span of railroad bridge as 'dumped and demolished' after a two thousand pound bomb hit. One span of the highway bridge was knocked flat.

Some Korean cities were literally "removed from the map" (Cumings 2004: 19) due to the massive carpet bombings by the American military. As a result, food provisions further deteriorated and became irregular during the war. A Korean remembers everyday life during the war as follows (Kim 1989: 37): 
Rice was hard to come by then: none of the stores were open ... We bought potatoes and barley and ate that, mixed with a little rice. People were making stew from zucchini leaves and whatever vegetables they could get, boiling them with some barley in lots of water.

The Korean War ended in an armistice in 1953, and a demilitarized zone (DMZ) close to the original dividing line (i.e. 38th parallel) of the two occupied Koreas was established.

Yet, living standards did not improve after the Korean War. Japanese exploitation during colonization, structural distortions after liberation, the artificial division of the peninsula into two Koreas, and the Korean War altogether led to rampant corruption and spread of black markets in the South (Lie 1998:32). Unlike socialist North Korea, which installed a food rationing system for ideological reasons (i.e. a public distribution system), people in the capitalist South were fighting a battle of survival of the fittest, where individuals bribing government officials were altering the odds in their favor (Lie 1998:33). Access to scarce resources such as food and medicine were primarily subject to bribery after the war. Due to extreme poverty, many officials barely made a living with their salary, thus becoming inevitably susceptible to bribery (Lie 1998:33). Entering a vicious circle of corruption and low economic growth, living standards of average Koreans were not good even a decade after the war. A South Korean remembers as follows (Kim and Yu 1997:37):

When I was growing up in Korea in the 1960s, life was very difficult. We were very regimented ... I faced a lot of economic hardships. We did not always have enough to eat.

Sometimes all of my family members had to share one egg.

Dissatisfied with the chaotic and corrupt government, the South Korean military launched a coup in 1961. As commonly known, the military government then rigorously advanced South Korea into the world's fastest growing economy of the second half of the twentieth century (Maddison 2001) and eventually to an OECD nation by the 1990s, which is beyond the scope of this paper.

\section{Data}

This study employs data from the Joseon Siksan Eunhaeng, which is today called the Korean Development Bank (KDB). The Joseon Siksan Eunhaeng (literally, "Korean Increasing Property Bank") was established in 1918 under Japanese colonization and was the largest bank in Colonial Korea, managing $41 \%$ of capital transactions, $28 \%$ of saving transactions, and $55 \%$ of loan transactions at that time. The Joseon Siksan Eunhaeng changed its name to Hanguk Saneop Eunhaeng (literally, "Korean Industrial Bank") after the Korean War, and its many branches can still be seen all over South Korea.

In colonial times, employment at the Korean Increasing Property Bank was highly competitive and a highly desired job position. Only one out of 30 candidates was selected, and there were two ways to land a job at the bank. First, high school or university graduates could apply for a job. Particularly, university education was strictly regulated by the Japanese, such that apparently only children of rich or influential Korean parents could attend such institutions and thus apply for a job at the bank. Secondly, people with respective career experience were recruited regardless of their educational status. However, as certain mathematical, reading, and writing skills were required 
in the banking industry, non-privileged Koreans were effectively barred from applying at the bank. Therefore, the present data only represent the upper socioeconomic stratum of interwar Korea.

Nevertheless, records on white-collar workers have been used in previous studies despite the fact that the data are commonly drawn from an upper socioeconomic stratum of a given population. For instance, Gill (1998) analyzed height data on South Koreans employed by the Korean Medical Health Insurance Corporation. Since they were government employees (mostly working as teachers in public schools), they were considered to be members of the mid-upper class. Morgan (2004) analyzed the height of Chinese men born during the period from 1880-1930 and working in state-run enterprises, mainly the Chinese National Railways and the Post and Telegraph Administration. These employees were deemed to be a somewhat higher socioeconomic class (on account of their education and employment in government posts).

\section{Analysis}

Successful applicants were physically examined in hospitals for their anthropometric measurements. Further background data such as gender, age, residence, education, and so forth were recorded. Table 1 shows all variables taken from records employed in this study. The total sample size was 89. BMI (weight in kilograms divided by the square of height in meters) was used as a proxy of biological living standards. Since BMI can be used for both men and women, both sexes were combined. Mean BMI was 22 units (Table 1). Men were strikingly over-represented in the current sample (91\%). It is unsurprising that fewer women were employed by the bank since white collar jobs require the ability to read and write. Traditionally, females had significantly higher illiteracy rates than men due to Confucian gender discrimination. As an illustration, only $16 \%$ of Korean males were illiterate as opposed to 40\% of Korean females in 1960 (McGinn et al., 1980). Since the UN World Health Organization recommends using BMI for adults aged 20 or over, all teenage workers were excluded from the analysis. The mean age of individuals in this sample is 24 , with a minimum age of 20 and maximum age of 38. The mean measurement year is 1948, with a minimum year of 1941 and maximum year of 1956. Most individuals (58\%) were residing in Southern Korea (Jeolla Province, Jeju Island, Gyeongsang Province), followed by Central Korea (Chungcheong Province, Gangwon Province), the capital Seoul, and Northern Korea (Pyongan Province). A majority $(74 \%)$ had a high school or higher education (high school degree or tertiary educational degree), as opposed to $26 \%$ with a lower education (primary or secondary degree only). In comparison, only 18\% of Koreans were enrolled in high school and 3\% in college in 1955 (McGinn, Snodgrass et al. 1980). About $65 \%$ of individuals in this sample specified that their fathers were farmers (or working in farming-related business). In comparison, about $85 \%$ of the Korean labor force was employed in agriculture in 1910 (Jun 2012), indicating that the parents of individuals in the sample were more often of higher socioeconomic status as opposed to commoners. Moreover, due to numerous missing values, the subsample size substantially drops from 89 to 37 individuals. We therefore limit our analysis of BMI values to measurement year and region. 


\section{Table 1: Descriptive statistics}

\begin{tabular}{|c|c|c|c|c|c|c|}
\hline Variables & $\mathrm{N}$ & Percent & Min & Max & Mean & $S D$ \\
\hline $\mathrm{BMI}$ & 89 & & 17.5 & 34.0 & 21.5 & 2.4 \\
\hline Current age in years & 89 & & 20.0 & 38.0 & 23.6 & 4.2 \\
\hline Measurement year & 89 & & 1936 & 1956 & 1948 & 3.9 \\
\hline
\end{tabular}

Gender male

$81 \quad 91$

Gender female

89

Subtotal

$89 \quad 100$

Northern Korea

$2 \quad 2$

Central Korea

$26 \quad 29$

Southern Korea

$52 \quad 58$

Current residence Seoul

$9 \quad 10$

Subtotal

$89 \quad 100$

Lower education

$22 \quad 26$

High school or higher education

$62 \quad 74$

Total

$84 \quad 100$

Father farmer

$24 \quad 64.9$

Father non-farmer

$13 \quad 35.1$

Subtotal

$37 \quad 100$

$\mathrm{BMI}$ is taken as an indicator of biological living standards, with higher values indicating better living conditions. BMI is stratified by measurement period and residence at time of measurement, and the values are plotted in Figure 1.

Our analysis reveals that individuals measured in the post-War period (1954-1956) had the lowest BMI values across all measurement periods. As an explanation, it is likely that international 
relief aid was delivered during the Korean War, but massive and permanent grain imports only started in 1956 in the form of U.S. loans under the Public Law 480 (PL 480) program (Figure 2).

\section{Figure 1: BMI by time of measurement and residence at time of measurement}

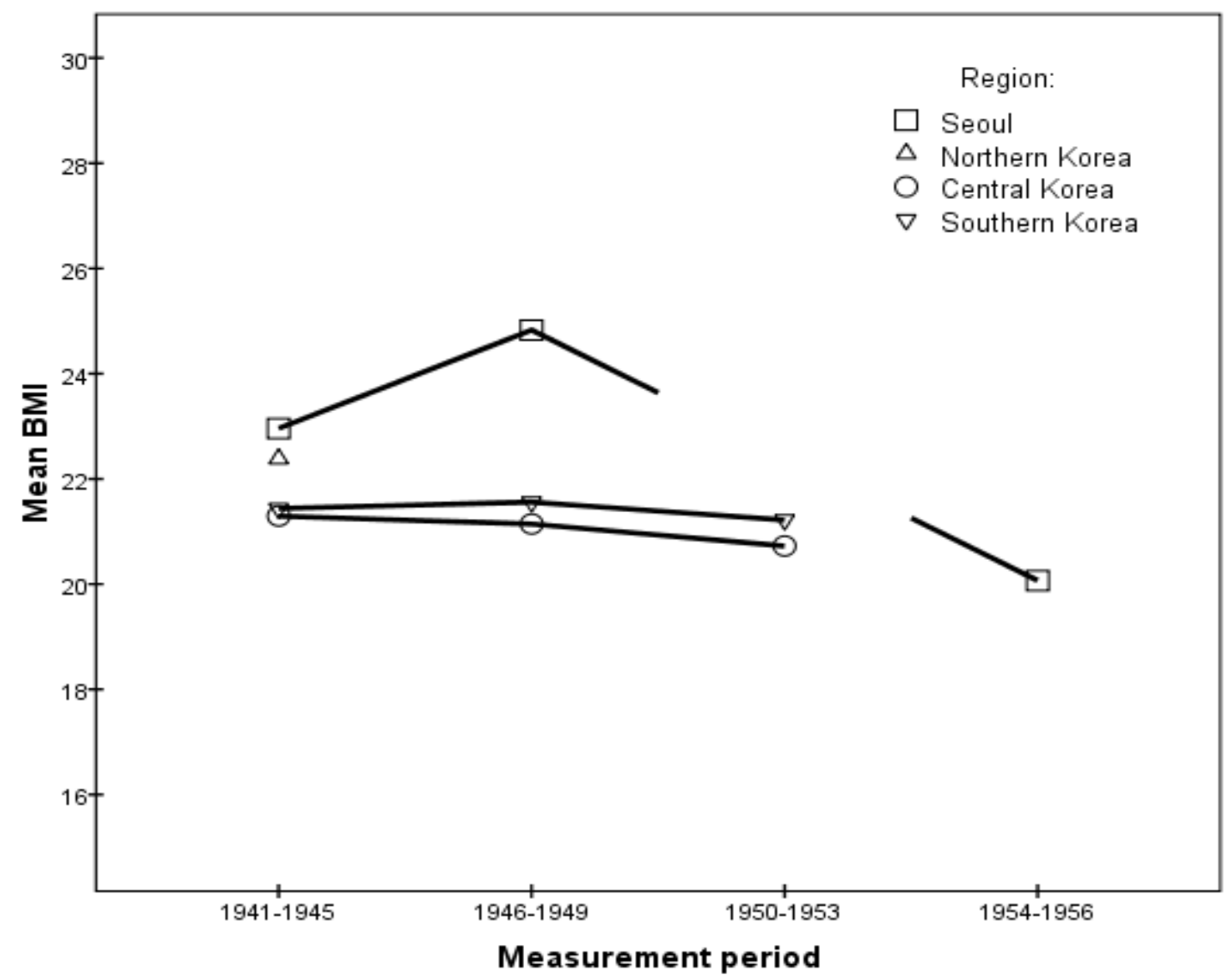

For illustration purposes, South Korea imported about 1,633,000 metric tons of grain from 1956 to 1960, 3,442,000 metric tons of grain from 1961 to 1965, and 4,426,000 metric tons of grains from 1966 to 1970s (Kim and Joo 1982:32). Most of these grains were given by the U.S. as a form of development aid to its Allies during the Cold War. In fact, South Korea became one of the major beneficiaries of the program since the U.S. heavily invested into the South to prevent its collapse and contain the Communist North. Hence, individuals measured in the immediate post-War period from 1954 to 1956 were obviously cut-off from relief aid and thus unable to benefit from the massive and permanent PL 480 program. 


\section{Figure 2: Grain imports to South Korea}

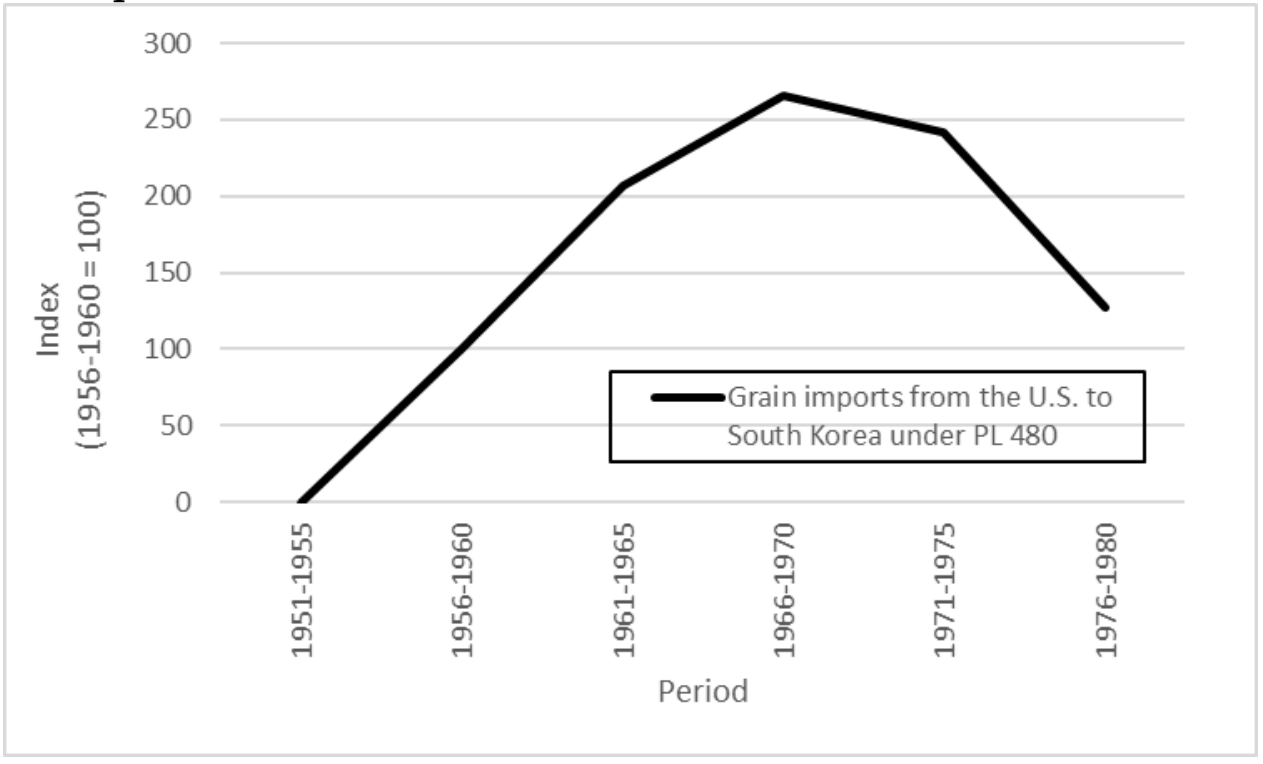

Source: Kim and Joo (1982:32).

Individuals measured in the interwar period (1946 to 1949) had a relatively high mean BMI. For instance, among residents in Seoul and Southern Korea, BMI peaked during the observed period.

Individuals measured during the critical Japanese war mobilization period (1941-1945) did not fare too poorly, during which time Korea was increasingly made a supply base for Japan's war efforts against the U.S. and its Allies. It is possible that Japan's war mobilization did not strongly impact the Korean peninsula, although further studies are needed to confirm this. Indeed, mean height slightly improved in the early years of Japanese colonization (Choi and Schwekendiek 2009; Kim and Park 2011), suggesting that biological living standards did not decline under colonial rule.

Expectedly, the Korean War (1950-1953) negatively affected the biological living condition of Koreans, although the post-Korean War period was, as discussed, much more detrimental. Another likely reason why the disruptive Korean War did not affect the sample was that the bank employees were shielded from starvation during the war due to their better networks and resources. As put by an average Korean housewife who barely escaped from the North Korean troops all the way from the capital Seoul to the port city of Pusan in the Southern tip of the peninsula during the war (Kim 1989:39):

I had earlier vowed to myself that no matter how badly off I was, I would never seek out Small Uncle [father's younger brother], because he had told us that he had no way to leave Seoul. We found out later that he had gone to Pusan in a truck sponsored by the bank where he worked. He took with him not only his entire family but even all his home furnishings. Now, with my [starving] child almost dead, there was nothing I could do but go to the bank branch in Pusan to find Uncle, who was surprised and a little embarrassed to see me. He took me to the place where he was staying with his family: it was a huge house, big enough to hold many families. The floors were heated and the people were cooking and eating almost normally, very unlike refugees. 
Given the low sample size, let alone the extremely low subsample sizes by region, one has to take the analysis with caution. Overall, one gets the impression that biological living standards first slightly improved during the occupation period, declined during the war period, and reached a trough in the post-War period. Moreover, BMI values were consistently larger in the capital Seoul compared to the other regions, perhaps due to better access to black markets and official food distribution centers.

\section{Comparison of findings}

How does the present sample compare to other historical populations? Table 2 provides a BMI comparison with nineteenth century white American males, whereas Table 3 references present data on males measured in pre-modern Korea, Colonial Korea, and contemporary South Korea.

Table 2: BMI status of interwar Koreans according to United Nations WHO classifications of BMI in comparative perspective with nineteenth century white Americans

\begin{tabular}{llclc}
\hline Target group & $\begin{array}{c}\text { Underweight } \\
\text { in } \%\end{array}$ & $\begin{array}{c}\text { Normal } \\
\text { weight in } \\
\%\end{array}$ & $\begin{array}{c}\text { Overweight Total } \\
\text { in } \%\end{array}$ & in $\%$ \\
\hline Nineteenth century white Americans (age 20s-30s) & 2.3 & 81.6 & 16.1 & 100 \\
Early twentieth century Koreans (age 20s-30s) & 5.6 & 87.6 & 6.7 & 100
\end{tabular}

Notes: Overweight rates include obesity rates.

Source: This study and Carson (2011).

While most studies on biological standard of living have focused on height due to its availability over the centuries, only a few historical studies have made use of BMI data. Carson (2011) analyzed the BMIs of nineteenth century American prisoners, whereas Komlos and Brabec (2012) focused on nineteenth to early twentieth century American military recruits. Only Carson (2011) reported detailed BMI data, allowing a comparison with the present sample (Table 2). However, BMI was reported according to international nutritional classifications. The BMI cut-offs for underweight, normal weight, and overweight individuals according to the UN World Health Organization are as follows: underweight $=$ BMI below 18.50, normal weight $=$ BMI 18.50 to 24.99, and overweight (including obesity) $=$ BMI 25.00 or higher. Table 2 shows that interwar Koreans were slightly more underweight $(6 \%)$ than white Americans (2\%) in the nineteenth century. Since Americans in that sample were from the lower stratum (prisoners) and Koreans in the current sample from the upper stratum (bank employees), underweight gaps between average Koreans and Americans were probably much larger.

Since BMI comparisons with other historical populations are difficult to make due to lack of data, Table 3 adds the results of previous studies on Korean height and weight. Mean height of interwar Koreans was $167 \mathrm{~cm}$, indicating a minor improvement compared to Joseon Dynasty Korea $(166 \mathrm{~cm})$ and Colonial Korea $(166 \mathrm{~cm})$. However, since interwar Koreans were from the upper socioeconomic stratum, Joseon Dynasty Koreans from the lower and middle strata (unfree 'slaves' 
and commoners), and those from Colonial Korea from the middle and lower strata (political prisoners), one should take this comparison with caution. Korean government employees (mostly teachers) born in 1954 had a final height of $169 \mathrm{~cm}$, but they were also from the upper social stratum since their mean income was 50\% higher than average (Gill, 1998). However, Koreans in the present sample $(167 \mathrm{~cm})$, who were born from the 1900 s to 1930s, were somewhat shorter than Korean government employees born some 25 years later $(169 \mathrm{~cm})$. Whether or not the bank employees in the current sample or government employees born in 1954 were of higher socioeconomic status cannot be determined. Lastly, comparison with a national sample of South Koreans born in the 1970s revealed that contemporary people are strikingly taller $(173 \mathrm{~cm})$ and heavier $(70 \mathrm{~kg})$ as well as have a higher BMI (24 units) than interwar Koreans $(167 \mathrm{~cm}, 60 \mathrm{~kg}, 22 \mathrm{BMI}$ units, respectively).

Table 3: BMI, height, and weight status of interwar Koreans in comparative perspective with premodern, colonial, and contemporary Koreans

\begin{tabular}{|c|c|c|c|c|c|c|}
\hline \multirow{2}{*}{$\begin{array}{l}\text { General } \\
\text { historical } \\
\text { period }\end{array}$} & \multirow[t]{2}{*}{ Sample } & \multirow{2}{*}{$\begin{array}{l}\text { Measurement } \\
\text { period }\end{array}$} & \multirow{2}{*}{$\begin{array}{l}\text { Birth } \\
\text { period }\end{array}$} & \multicolumn{3}{|c|}{ Anthropometrics } \\
\hline & & & & $\begin{array}{c}\text { Mean } \\
\text { BMI }\end{array}$ & $\begin{array}{l}\text { Mean } \\
\text { height } \\
\text { in } \mathrm{cm}\end{array}$ & $\begin{array}{l}\text { Mean } \\
\text { weight } \\
\text { in } \mathrm{kg}\end{array}$ \\
\hline $\begin{array}{l}\text { Joseon } \\
\text { Dynasty } \\
\text { Korea } \\
(1392 \text { to } \\
1910)\end{array}$ & $\begin{array}{l}\text { Militia recruits } \\
\text { (males aged 20- } \\
40 \text { ) }\end{array}$ & 1590 s to $1720 \mathrm{~s}$ & $\begin{array}{l}\text { Mid sixteenth to } \\
\text { early eighteenth } \\
\text { century }\end{array}$ & $\mathrm{n} / \mathrm{a}$ & 165.69 & $\mathrm{n} / \mathrm{a}$ \\
\hline $\begin{array}{l}\text { Colonial } \\
\text { Korea } \\
(1910 \text { to } \\
1945)\end{array}$ & $\begin{array}{l}\text { Political } \\
\text { prisoners } \\
\text { (males aged 20- } \\
40 \text { ) }\end{array}$ & 1910 s to $1940 \mathrm{~s}$ & 1890 s to $1910 \mathrm{~s}$ & $\mathrm{n} / \mathrm{a}$ & 164.46 & $\mathrm{n} / \mathrm{a}$ \\
\hline $\begin{array}{l}\text { Occupied } \\
\text { Korea } \\
(1945 \text { to } \\
1948) \text { and } \\
\text { Korean } \\
\text { War (1950 } \\
\text { to } 1953)\end{array}$ & $\begin{array}{l}\text { Bank } \\
\text { employees } \\
\text { (males aged 20- } \\
\text { 30s), this study }\end{array}$ & 1930 s to $1950 \mathrm{~s}$ & 1900 s to $1930 \mathrm{~s}$ & 21.50 & 167.07 & 59.98 \\
\hline $\begin{array}{l}\text { Republic } \\
\text { of Korea } \\
\text { (1948 to } \\
\text { present) }\end{array}$ & $\begin{array}{l}\text { A: Government } \\
\text { employees } \\
\text { (males aged 20- } \\
40 \text { ) }\end{array}$ & 1994 & 1950 s to $1970 \mathrm{~s}$ & $\mathrm{n} / \mathrm{a}$ & $\begin{array}{c}169.27 \\
\text { (in 1954) }\end{array}$ & $\mathrm{n} / \mathrm{a}$ \\
\hline
\end{tabular}




$\begin{array}{lllll}\text { B: National 2002-2003 } & \text { 1970s } & 23.56 & 172.50 & 70.10 \\ \text { random sample } & & & & \\ \text { (males aged 25- } & & & & \end{array}$

29)

Notes: The BMI of national random sample was calculated based on reported mean height and weight.

Source: This study and Lewis et al. (2013:261), Choi and Schwekendiek (2009:260), Schwekendiek and Jun (2010), Korean Agency for Technology and Standards (2004:90, 120).

\section{Conclusion}

In summation, the biological standard of living in Korea has been widely studied since the Korean peninsula offers a rare opportunity to investigate the effects of colonialism, capitalism, and communism. However, previous studies have focused on Joseon Dynasty Korea, Colonial Korea, South Korea, and North Korea by employing human height measurements. The present study fills a gap in the literature by employing BMI measurements of interwar Koreans measured from the early 1940s to mid-1950s. This period is of special historical concern since it coincides with the end of World War II, during which Japan utilized the Korean peninsula as a supply base, the chaotic foreign occupation period of Korea (1945-1948), the Korean War (1950-1953), and the early years after the war. This study is based on records of employees from a large Korean bank, most of whom were of upper socioeconomic status. BMI values reached a trough in the latter period, indicating that biological living standards must have declined after the war. While the war destroyed Korea's economy, relief aid prevented the total collapse during war times. However, international massive grain programs such as the PL 480 program were still not implemented, leaving people vulnerable directly after the war. Unexpectedly, BMI values were the highest during the chaotic occupation period. Most individuals were probably shielded from economic depression at that time due to their higher socioeconomic status. The latter result is broadly in line with a study on final height of Germans born during World War I (Blum 2013), suggesting that wealthier individuals were more likely to purchase food on the black market.

\section{Acknowledgements}

This work was supported by the Ministry of Education of the Republic of Korea and the National Research Foundation of Korea (NRF-2018S1A6A3A01023515). The authors would like to thank Seong-Min Paek for his assistance to compile the data. We also thank two anonymous reviewers for their very helpful suggestions to improve this paper.

\section{Authors}

Daniel Schwekendiek

Sungkyunkwan University

danjosch@skku.edu

Heejin Park 
Kyungpook National University

\section{Publishing Timeline}

Received 28 August 2018

Accepted 14 October 2019

Published 1 February 2020

\section{References}

Baten, J. and M. Blum (2012). "Growing tall but unqueal: New findings and new background evidence on anthropometric welfare in 156 countries, 1810-1989." Economic History of Developing Regions 27(S66S88).

Blum, M. (2013). "War, food rationing, and socioeconomic inequality in Germany during the First World War." Economic History Review 66(4): 1063-1083.

Carson, S. (2011). The cliometrics of BMI and obesity. The Oxford handbook of the social science of obesity. J. Cawley. Oxford and New York, Oxford University Press: 48-59.

Choi, S.-J. and D. Schwekendiek (2009). "The biological standard of living in Colonial Korea, 1910-1945." Economics and Human Biology 7(2): 259-264.

Cumings, B. (2004). North Korea: Another Country. New York, New York Press.

Eargle, F. (1952). Korean War Diary. Raleigh, Lulu Publishers.

Giersch, H., K.-H. Paqué, et al. (1992). The Fading Miracle: Four Decades of Market Economy in Germany. Cambridge, Cambridge University Press.

Jun, S. H. (2012). "Rethinking the Miracle on the Han River: On the Road to Successful Laissez-faire Market Economies." InfoKorea(February 2012): 50-55.

Kang, H. (2001). Under the black umbrella. Voices from Colonial Korea, 1910-1945. Ithaka, Cornell University Press.

Kim, D.-H. and Y.-J. Joo (1982). The food situation and policies in the Republic of Korea. Paris, OECD.

Kim, D. and H. Park (2011). "Measuring living standards from the lowest: height of the male Hangryu deceased in colonial Korea." Explorations in Economic History 48: 590-599.

Kim, E. (1989). War story. Making Waves. A. W. U. o. C. E. by. Boston, Beacon Press: 33-42.

Kim, E. and E.-Y. Yu (1997). East to America: Korean American Life Stories New York, The New Press.

Kimura, M. (1993). "Standards of living in colonial Korea: Did the masses become worse off or better off under Japanese rule?" Journal of Economic History 53(3): 629-52.

Koepke, N. and J. Baten (2005). "The Biological Standard of Living in Europe During the Last Two Millennia." European Review of Economic History 9(1): 61-95.

Komlos, J. and J. Baten, Eds. (1998). The biological standard of living in comparative perspective. Stuttgart, Steiner.

Komlos, J. and M. Brabec (2012). The transition to post-industrial BMI values in the United States. Insecurity, inequality and obesity in affluent societies. A. Offer, R. Pechey and S. Ulijaszek. Oxford and New York, Oxford University Press: 141-160.

Komlos, J. and P. Kriwy (2003). "The biological standard of living in the two Germanies." German Economic Review 4(4): 459-473.

Korean Agency for Technology and Standards (2004). Je5cha hangugin inchechisujosasaeop bogoseo Gwachon, Korean Agency for Technology and Standards.

Lewis, J. B., S. H. Jun, et al. (2013). "Toward an Anthropometric History of Chosŏn Dynasty Korea, Sixteenth to Eighteenth Century." Journal of the Historical Society 13(3): 239-270.

Lie, J. (1998). Han Unbound: The political economy of South Korea. Stanford, Stanford University Press. 
Maddison, A. (2001). The World Economy. A Millennial Perspective. Washington, DC, OECD.

McGinn, N., D. Snodgrass, et al. (1980). Education and development in Korea. Cambridge and London, Harvard University Press.

Nahm, A. C. (1993). Introduction to Korean History and Culture. New Jersey, Hollym.

Pak, S. (2004). "The biological standard of living in the two Koreas." Economics and Human Biology 2(3): 511-521.

Pak, S. (2011). "An Estimation of Adult Males' Average Stature from the Skeletal Remains of Joseon Period [in Korean]." Korean Journal of Physical Anthropology 11(4): 185-193.

Schwekendiek, D. (2008). "Determinants of well-being in North Korea: evidence from the post-famine period." Economics and Human Biology 6(3): 446-454.

Schwekendiek, D. (2008). "The North Korean standard of living during the famine." Social Science and Medicine 66(3): 596-608.

Schwekendiek, D. and S.-H. Jun (2010). "From the poorest to the tallest in East-Asia: The secular trend in height of South Koreans." Korea Journal 50(3): 151-175.

Shin, D. H., C. S. Oh, et al. (2012). "Ancient-to-Modern Secular Changes in Korean Stature." American Journal of Physical Anthropology 147: 433-442.

Steckel, R. (1995). "Stature and the standard of living." Journal of Economic Literature 33: 1903-1940.

Steckel, R. (2009). "Heights and human welfare: Recent developments and new directions." Explorations in Economic History 46(1): 1-23.

Steiner, A. (2010). The Plans that Failed: An Economic History of the GDR. New York and Oxford, Berghan Books. 